\title{
STRATEGI PENINGKATAN OCCUPANCY RATE DAN AVERAGE ROOM RATE PADA MASA PANDEMI COVID-19 DI HOTEL NOORMANS SEMARANG
}

\author{
Izza Ulumuddin Ahmad Asshofi, Prima Setia Judha Pranata
}

izza.asshofi@dsn.dinus.ac.id

Universitas Dian Nuswantoro

\begin{abstract}
The Covid-19 pandemic has caused unrest for all citizens of the world in the health, trade, economy, security, politics, transportation, human mobility and tourism sectors. As the second largest contributor to foreign exchange in Indonesia in 2019, tourism, especially hospitality, has experienced a significant decline in business. Starting from canceling room reservations to canceling various activities at the hotel. As a consequence, the hotel occupancy rate and average room rate dropped dramatically to $10 \%$ - 25\%. This was also experienced by Hotel Noormans Semarang, which only had an occupancy rate of $15 \%$ in April 2020 with an average room rate below the price of IDR 300,000.00. The aim of this paper is to observe the strategy to increase the occupancy rate and average room rate during the Covid-19 pandemic at the Hotel Noormans Semarang. This research was designed with a descriptive qualitative paradigm. This research shows that the strategy of increasing the occupancy rate and average room rate during the pandemic at Noormans hotels in 2020 does not show positive results. However, what happened was the opposite, a decline from 2019 to 2020. The occupancy rate decreased from $70 \%$ to $36 \%$ and the average room rate decreased from IDR 332,094.00 to IDR 258,250.00.
\end{abstract}

Keywords: occupancy rate, average room rate, hotel, Covid-19

Akhir-akhir ini kondisi dunia sedang dihebohkan dengan sebuah kasus baru di dunia kesehatan manusia berupa penyakit menular. Penyakit menular tersebut dikenal dengan Corona Virus Disease (Covid-19). Kasus yang pertama kali di Indonesia terungkap pada 2 Maret 2020. Sebuah virus yang disebut berasal dari Wuhan, China tersebut pada awalnya positif menginfeksi 2 orang warga negara Indonesia setelah berinteraksi dengan orang Jepang yang terinfeksi dan berkembang hingga mencapai 5.516 orang positif terinfeksi, 548 orang sembuh dan 498 orang meninggal dunia di Indonesia (www.covid19.go.id, diakses tanggal 16 April 2020). Badan kesehatan dunia (WHO) per tanggal 11 Maret 2020 menyatakan bahwa Covid-19 ini sudah 
menjadi pandemik global karena dalam waktu kurang dari tiga bulan sudah mewabah di 123 negara di dunia (www.who.int, diakses tanggal 15 April 2020) dengan jumlah kasus mencapai 2.089.617 orang positif terinfeksi, 516.202 orang sembuh dan 134.809 orang meninggal (www.ourworldindata.org/coronavirus, diakses tanggal 16 April 2020). Kebijakan WHO tersebut juga diikuti dengan anjuran untuk melakukan social distancing. Dengan perkembangan kasus yang semakin memburuk, WHO pun membuat anjuran untuk meningkatkan kewaspadaan dengan kebijakan physical distancing. Kebijakan-kebijakan tersebut juga diberlakukan di Indonesia mengingat kondisi wabah yang terjadi sebagai bentuk pencegahan penularan.

Social distancing dan physical distancing bisa diartikan dengan kebijakan untuk tidak berada di keramaian atau kerumunan orang. Definisi tersebut secara luas bisa diartikan sebagai tindakan untuk tidak melakukan perkumpulan, pertemuan, pesta, konvensi, dan acara yang bisa mengumpulkan massa dalam jumlah banyak orang. Oleh karena itu, muncullah anjuran secara spesifik untuk melakukan kegiatan belajar, bekerja dan beribadah dari rumah.

Mengacu pada UU No. 6 tahun 2018 perihal Kekarantinaan Kesehatan, Presiden Indonesia membuat kebijakan tambahan dengan menetapkan PP No. 21 tahun 2020 tentang Percepatan Penanganan Corona Virus Disease (Covid-19) tentang Pembatasan Sosial Berskala Besar (PSBB). Dalam praktiknya PSBB ini diterapkan dengan model usulan pemerintah daerah yang disetujui oleh Kementerian Kesehatan RI. Dengan adanya PSBB, batasan yang dibuat terhadap aktivitas masyarakat menjadi semakin luas dan ketat.

Salah satu dampak yang dirasakan dari semakin meningkatnya kasus positif terinfeksi Covid-19 di Indonesia dan kebijakan-kebijakan yang diterapkan adalah di bisnis pariwisata khususnya di bidang industri perhotelan dan restoran. Berdasarkan data Laporan Perkembangan di Lingkup Industri Perhotelan dan Restoran terkait wabah Covid-19 yang dirilis oleh PHRI tanggal 15 Maret 2020 dinyatakan bahwa terjadi penurunan tingkat hunian kamar (occupancy rate) hotel berkisar antara $25 \%$ $50 \%$ dan penurunan rata-rata harga kamar (average room rate) berkisar antara $10 \%$ - 
Izza Ulumuddin Ahmad Asshofi, Prima Setia Judha Pranata, Strategi Peningkatan Occupancy Rate dan Average Room Rate pada Masa Pandemi Covid-19 di Hotel Noormans Semarang

25\%. Data tersebut jika dibandingkan dengan periode yang sama berjalan pada tahun 2019. Khusus di Jawa Tengah, selama dua pekan di awal Maret 2020 tingkat okupansi hotel berada di antara $25 \%$ hingga $35 \%$. Mirisnya, dengan kondisi pandemic yang belum menunjukkan tanda berakhir, PHRI pusat pun merilis data hotel yang ditutup pada 13 April 2020. Hasilnya, ada 1642 hotel yang ditutup operasinya di seluruh Indonesia, dan 83 di antaranya ada di Jawa Tengah. Meskipun kondisi yang terjadi sedemikian parahnya, Hotel Noormans Semarang masih tetap beroperasi hingga kini dengan occupancy rate 15\% pada bulan April 2020 dengan average room rate di bawah Rp. 300.000,--.

Pada tanggal 1-14 Maret 2020 secara nasional Occupancy rate telah menurun hingga di bawah 50\%, yang menunjukan bahwa sektor hotel telah mengalami kesulitan cash flow dan kerugian. Hal ini terjadi sejak beberapa Kementerian dan Lembaga Negara yang memberikan instruksi khusus untuk tidak mengadakan berbagai jenis pertemuan yang mengumpulkan banyak orang. Bagi sektor hotel sgemen pemerintah masih menjadi sangat dominan di seluruh wilayah Indonesia termasuk Hotel Noormans Semarang.

Menyusutnya cash flow perhotelan mengakibatkan kemampuan dalam membayar hutang perbankan, pajak (pajak pemerintah pusat, pajak dan retribusi daerah), urunan BPJS Ketenagakerjaan, urunan BPJS Kesehatan dan biaya operasional lainnya (gaji, air, listrik, supplier bahan baku, dan sebagianya) menjadi melemah dan ada probabilitas gagal bayar apabila kebijakan untuk mengantisipasinya tidak dieksekusi dengan cerdas. Manajemen hotel sedang membuat atau bahkan memprediksikan kemungkinan terburuk kepada karyawan untuk mengurangi biaya staf dengan mengatur masuk secara bergiliran, merumahkan sebagian karyawan, mengurangi durasi jam kerja, menghentikan total pekerja harian lepas dan menunda atau malah mengurangi pembayaran THR yang tidak $100 \%$

Mencermati operasional bisnis di industri perhotelan tahun 2020 ini, praktis hanya ada bulan Januari dan Februari terjadi bisnis yang murni karena belum terdampak wabah. Berdasarkan keterangan Badan Pariwisata Dunia (UNWTO) dan 
Dewan Pariwisata dan Perjalanan Dunia (WTTC), apabila dalam dua bulan tersebut industri pehotelan mengalami profit, maka proftinya akan digunakan untuk operasional di bulan Maret. Selebihnya pada April - Desember adalah bulan-bulan terdampak dari adanya Covid-19 ini. Kondisi ini akan mengalami stabilisasi pada Januari 2020 jika pandemik global ini dapat ditangani dengan baik di masing-masing negara.

Dampak dari adanya pandemik Covid-19 ini diperkirakan Kementerian Pariwisata Indonesia membutuhkan waktu paling tidak 6-12 bulan untuk pemulihan setelah dinyatakan pandeminya selesai (www.tagar.id, diakses tanggal 16 April 2020). Artinya, jika pandemik ini berakhir pada bulan Juni 2020, maka paling cepat pada Januari 2021 atau bahkan bisa mencapai Juni 2021 bisnis pariwisata khususnya bidang industri perhotelan baru akan bertumbuh kembali. Hal ini juga bisa dimaknai bahwa bisnis industri perhotelan pada tahun 2020 ini mengalami penurunan secara keseluruhan baik itu dari sisi tingkat hunian, tingkat rata-rata harga kamar, dan total pendapatan dari industri perhotelan. Di sisi lain, dengan kondisi anjlok di tahun 2020 ini, sangat penting untuk melihat potensi setelah pandemik ini berakhir. Fenomena yang terjadi saat ini adalah kelas menengah masyarakat banyak yang work from home. Hal ini bisa menjadi alasan kuat bahwa merekalah yang bakal menjadi cikal bakal potensi lonjakan wisatawan yang signifikan di tahun depan.

Dalam situasi yang tidak menentu saat ini, peneliti memandang Hotel Noormans telah melakukan langkah - langkah efisiensi untuk bisa bertahan, di antaranya:

1. Tidak menerima karyawan magang, meskipun mereka biasanya tidak diberi upah, tetapi hotel biasanya menyediakan jatah satu kali makan untuk karyawan magang. Hal ini berdampak pada institusi pendidikan yang akan mengirimkan anak didiknya untuk magang di hotel menjadi terhambat atau bahkan batal. 
Izza Ulumuddin Ahmad Asshofi, Prima Setia Judha Pranata, Strategi Peningkatan Occupancy Rate dan Average Room Rate pada Masa Pandemi Covid-19 di Hotel Noormans Semarang

2. Karyawan harian lepas tidak dipanggil lagi untuk bekerja. Hal ini dilakukan untuk mengoptimalkan kinerja jumlah karyawan kontrak/ tetap yang sudah bekerja di industri perhotelan.

3. Karyawan kontrak tidak diperpanjang kontraknya. Dengan momentum rendahnya pemasukan dari operasional bisnis, industri perhotelan juga melakukan efisiensi dengan pengurangan karyawan kontrak yang habis masa kontraknya tanpa diperpanjang.

4. Karyawan kontrak dipaksa cuti tanpa dibayar (unpaid leave). Industri perhotelan terpaksa menerapkan pola ini mengingat operasional bisnis yang tidak memerlukan jumlah karyawan dalam kondisi bisnis sedang tumbuh.

5. Industri perhotelan sedikit menurunkan "grade" mereka dengan menjual paket rice bowl atau nasi kotak/ bento dengan pola delivery dengan harga yang lebih murah dari standar harga hotel pada umumnya.

Peneliti menilai saat ini adalah suatu momentum terkini yang tepat untuk menemukan strategi peningkatan occupancy rate dan average room rate pada masa pandemi Covid-19 di Hotel Noormans Semarang.

\section{TINJAUAN PUSTAKA}

\section{Strategi Bisnis}

Strategi diambil dari kata Yunani strategeia (stratus $=$ militer dan ag $=$ memimpin), yang berarti seni atau ilmu untuk menjadi jenderal. Kondisi zaman dulu yang sering terjadi perang, menjadikan konsep ini sangat relevan pada waktu itu. Seorang jenderal dibutuhkan oleh angkatan perang agar dapat selalu memenangkan peperangan. Dalam dunia bisnis, tidak jarang konsepnya mengadopsi dari konsep strategi militer. Dalam kata lain, strategi merupakan gambaran dan arahan dalam berbisnis dengan menyesuaikan lingkungan yang dipilih dan digunakan sebagai pedoman dalam memberdayakan sumber daya dan usaha suatu organisasi.

Menurut David (2011), strategi bisnis merupakan suatu alat dalam mencapai tujuan berjangka panjang. Dalam menggapai kesinambungan manfaat yang kompetitif, 
perusahaan perlu untuk (1) terus beradaptasi dalam mengidentifikasi tren eksternal dan kapasitas internal, kemampuan dan sumber daya; dan (2) Merencanakan secara efektif, mengimplementasikan dan mengevaluasi strategi agar dapat berperan optimal.

Sementara definisi strategi menurut Rangkuti (2015) merupakan alat untuk mencapai tujuan perusahaan dalam kaitanya dengan tujuan jangka panjang, program tindak lanjut serta prioritas alokasi sumber daya. Dengan demikian, strategi itu bukan dimulai dari apa yang terjadi, tetapi dimulai dari kemungkinan apa yang kemudian dapat terjadi. Dalam hal ini, perlunya menemukan kompetensi inti dari suatu perusahaan termasuk industri perhotel sehingga mampu menghdapai kecepatan pasar dalam berinovasi, pandemi yang sedan melanda dan perubahan pola konsumen.

\section{Occupancy Rate dan Average Room Rate}

Ada faktor keberhasilan internal dan eksternal di sektor industri jasa yang dilakukan oleh peneliti yang menemukan beberapa faktor internal yang berkontribusi terhadap akomodasi perhotelan yang mengesankan (Abdullah, 2012). Menurutnya, kebersihan, lokasi, room rate dan keamanan di antara faktor-faktor terpenting. Cukup menarik karena kebersihan berkontribusi terhadap keberhasilan internal hunian hotel.

Dengan keragaman demografi, kebutuhan dan tuntutan orang juga beragam. Pria dan wanita, dewasa dan pelanggan yang lebih muda semuanya memiliki kebutuhan dan harapan yang berbeda. Akibatnya, dampaknya terhadap keberhasilan industri perhotelan juga berbeda. Pelanggan yang puas akan meningkatkan bisnis dengan occupancy rate dan average room rate yang signifikan, sedangkan pelanggan yang tidak puas akan memiliki efek merusak pada bisnis. Oleh karena itu, kepuasan pelanggan adalah faktor yang harus dipantau dan dikelola seperti halnya aset fisik. Untuk mewujudkan ini, sebuah bisnis harus mampu mengidentifikasi kelemahan dan kekuatan perusahaan dan mengelolanya dengan baik dari dalam.

Penelitian Viglia (2016) menyelidiki efek online review dan efeknya terhadap occupancy rates. Penemuannya menunjukkan bahwa setelah mengendalikan variabel 
Izza Ulumuddin Ahmad Asshofi, Prima Setia Judha Pranata, Strategi Peningkatan Occupancy Rate dan Average Room Rate pada Masa Pandemi Covid-19 di Hotel Noormans Semarang

lain, peningkatan satu poin dalam skor ulasan (review score) berdampak pada peningkatan occupancy rate sebesar 7,5\%. Terlepas dari skor ulasan, jumlah ulasan memiliki efek positif, tetapi dengan laba yang menurun. Hal ini menyiratkan bahwa semakin tinggi jumlah ulasan, semakin rendah efek menguntungkan dalam hal tingkat hunian (occupancy rate).

Average Room Rate (ARR) merupakan harga rerata kamar yang dihasilkan dari penjualan kamar dalam satu malam oleh suatu hotel. ARR sering juga disebut dengan average daily rate (ADR). Harga kamar di suatu hotel itu tergantung kepada jenis kamarnya, maka dari harga yang bervariasi tersebut dapat diperoleh rata-rata harganya. Semakin tinggi occupancy rate, tidak menjamin bahwa average daily rate juga naik (Endar Sugiarto, 2004).

\section{COVID-19 Melumpuhkan Ekonomi Indonesia}

Saat ini merupakan ujian berat dalam menghadapi Covid-19 bagi seluruh dunia. Merebaknya virus Covid-19, memberikan dampak yang signifikan bagi perekonomian dunia dan Indonesia. Hal ini tentu terkait dengan pengaruh melemahnya perekonomian China. Menteri Keuangan Indonesia mengungkapkan bahwa pada bulan Februari 2020, Pengaruh pelemahan ekonomi China berpengaruh sekitar 0,3 - 0,6\% terhadap perekonomian Indonesia. Konsumsi barang impor luar negeri yang salah satunya dari China sebagai asal virus ini menyebar juga membuat masyarakat Indonesia resah dan khawatir dengan penyebaran virus Covid-19.

Kebijakan yang tepat dan jitu harus segera diantisipasi pemerintah untuk menghadapi dampak Covid-19 yang sangat besar demi keselamatan masyarakat dan perekonomian Indonesia. Kebijakan tersebut harus mengakomodasi sisi kesehatan, ekonomi dan keamanan untuk mitigasi dampak Covid-19. Kementerian Keuangan dan Bank Indonesia bisa diinstruksikan untuk menginisiasi kebijakan dengan program stimulus ekonomi untuk menggerakkan roda perekonomian. Kementerian Kesehatan dengan aksi tanggap pandemi, dan kementerian lain yang terkait dengan supporting system dan supporting policy lainnya. 
Sektor pariwisata menjadi sektor yang paling perlu diperhatikan setelah sektor kesehatan mengingat posisinya sebagai penyumbang pendapatan asli negara terbesar kedua. Efek menurunnya aktifitas pariwisata baik dari wisatawan domestik dan nondomestik membuat pemerintah menambahkan anggaran berupa insentif sebesar Rp. 298,5 miliar dan diskon 30\% dari 25\% kursi penerbangan ke-10 daerah wisata prioritas untuk wisatawan domestik. Selain itu, pajak hotel di 10 daerah wisata dibebaskan, meliputi 33 kabupaten/kota dengan kompensasi dari pemerintah pusat sebesar 3,3 triliun untuk penerimaan pemerintah daerah.

Ketika penanganan pandemi dan kesehatan berjalan dengan baik maka pergerakan sektor pariwisata berpeluang untuk pulih. Hal ini diharapkan dapat menekan efek keresahan baik dari sisi kesehatan, ekonomi dan keamaman dari munculnya virus ini dalam dapat ditekan seminimal mungkin.

\section{METODE PENELITIAN}

\section{Desain Penelitian}

Penelitian ini didesain dengan paradigma kualitatif deskriptif, yaitu paradigma yang berhubungan dengan ide, persepsi, pendapat dan kepercayaan informan yang diteliti. Peneliti sekaligus berperan menjadi instrumen penelitian dalam pengumpulan dan analisis data melalui proses observasi lapangan, wawancara, dan studi dokumen. Peneliti juga terlibat langsung sejak awal hingga akhir. Penelitian deskriptif mencoba mencari deskripsi yang tepat yang cukup dari semua aktivitas, objek, proses, dan manusia. Penelitian deskriptif berkaitan dengan pengumpulan fakta dan data secara valid untuk memberikan gambaran mengenai objek yang diteliti (Sulistyo, 2010). Hal ini dimaksudkan untuk memperoleh informasi berkaitan dengan strategi peningkatan bisnis yang dijalankan industri perhotelan di tengah pandemi Covid-19 di Hotel Noormans Semarang khususnya dari sisi sisi tingkat hunian kamar (occupancy rate) dan tingkat rata-rata harga kamar (average room rate) secara komprehensif dan mendalam untuk mengungkap situasi, permasalahan, dan solusi mengenai strategi 
Izza Ulumuddin Ahmad Asshofi, Prima Setia Judha Pranata, Strategi Peningkatan Occupancy Rate dan Average Room Rate pada Masa Pandemi Covid-19 di Hotel Noormans Semarang

yang tepat yang bisa diterapkan bagi Hotel Noormans di tengah pandemi global Covid-19.

Sumber data bersifat snowball sampling dan dipilih secara purposive. Snowball sampling merupakan teknik pengambilan sumber data yang pada awalnya jumlahnya sedikit dan lama-lama menjadi besar. Purposive sampling merupakan teknik pengambilan sampel sumber data dengan pertimbangan tertentu untuk memudahkan peneliti menjelajahi objek atau situasi sosial yang diteliti. (Sugiyono, 2018). Hal ini perlu dilakukan karena jumlah sumber data yang sedikit itu belum mampu memberikan data yang dibuthkan secara komplit sehingga perlu mencari data dari sumber lain baik itu data primer dan sekunder.

Teknik pengumpulan data yang dipakai menggunakan metode observasi lapangan, wawancara dengan Sales Manager, Front Office Manager dan General Manager Hotel Noormans yang sekaligus merupakan Ketua Indonesian Hotel and General Manager (IHGM) Jawa Tengah serta ditambah dengan studi literatur. Wawancara dilakukan dengan semi terstruktur sehingga pertanyaan terbuka dan bisa dikembangkan jika dianalisis secara mendalam. Tahapan yang dipakai dalam Teknik analisis data adalah Model Spradley. Tahapan ini terdiri dari tahap analisis domain, analisis taksonomi, analisis komponensial, dan analisis tema kultural. Pengujian Keabsahan data difokuskan pada uji validitas dan reliabilitas untuk dapat ditarik sebagai simpulan penelitian.

\section{HASIL DAN PEMBAHASAN}

\section{Gambaran Hotel Noormans Semarang}

Hotel Noormans Semarang merupakan salah satu hotel yang masih bertahan dan tidak ditutup operasionalnya melalui langkah-langkah efisiensinya di masa pandemik global Covid-19. Pada penelitian ini data diambil pada rentang waktu April - Desember 2020. 
Hotel Noormans Semarang dinilai sebagai hotel bintang 3+ di Kota Semarang. Desain interiornya berarsitektur mediterania klasik. Berlokasi sangat dekat dengan pintu keluar tol Jatingaleh. Hotel ini dapat ditempuh dari Bandara Internasional Ahmad Yani sekitar 20 menit. Restoran, arena perbelanjaan, Simpang Lima sebagai pusat kota dan tempat-tempat menarik lainnya mudah diakses dari hotel ini. Layanan dan fasilitas Hotel Noormans Semarang berjumlah 114 kamar. Tipe kamar yang tersedia mencakup 2 kamar Noormans suite, 21 kamar Deluxe Premier, 4 kamar Bisnis, dan 87 kamar Superior. Fasilitas lainnya terdapat restoran dan lounge De Jawis, Petra Ballroom, dan ruang pertemuan Kanaya dan Samara serta lahan parkir untuk 100 mobil.

\section{Revitalisasi Hotel Brand}

a. Meneguhkan kembali Greeting Good Days. Jadi staf hotel tidak lagi menyapa dengan selamat pagi, siang, sore dan malam, tetapi selalu menyapa dengan Good Days di setiap waktu.

b. Mereposisi Good Stay, Good Business sebagai tagline hotel sebagai kampanye hotel yang layak untuk tinggal dan berbisnis.

c. Good Booking, Good Price digunakan sebagai media promosi melalu web hotel dengan jaminan mendapatkan harga bagus dan informasi yang tepat untuk kepuasan tamu.

d. Deklarasi pemenuhan sertifikasi standar CHSE (Cleanliness, Health, Safety, and Environmental Sustainability) yang diterbitkan oleh Kemenparekraf. Meskipun hampir tidak ada tamu yang menanyakan tentang hal ini, tetapi ini digunakan sebagai upaya hotel dalam komitmennya menerapkan protokol kesehatan di masa pandemi.

\section{Optimalisasi Konten Digital Marketing}

Dalam strategi ini, WhatsApp blast menjadi kunci untuk meraih engagement dengan tamu yang pernah berbisnis dengan hotel Noormans dan dilakukan setiap 2-4 pekan sekali. -Menyapa kembali tamu yang pernah menjadi mitra bisnis sebagai 
Izza Ulumuddin Ahmad Asshofi, Prima Setia Judha Pranata, Strategi Peningkatan Occupancy Rate dan Average Room Rate pada Masa Pandemi Covid-19 di Hotel Noormans Semarang

relationship marketing. Tambahan pula, penonton konten hotel di Youtube mengalami kenaikan hingga 420 kali ditonton, yang sebelumnya hanya sekitar 175 kali ditonton. Instagram digunakan untuk membuat interaksi lebih dekat dengan tamu. Salah satunya melalui giveaway voucher kamar hotel. Sedangkan reservasi via web dapat dikatakan sangat minim karena tamu lebih memilih melakukan reservasi via online travel agent.

\section{Mengoptimalkan Penjualan pada Online Travel Agent (OTA)}

Dari sekian banyaknya pilihan OTA yang tersedia, Traveloka, Agoda dan Tiket.com merupakan OTA berposisi terdepan dalam melayani reservasi dengan proporsi antara $70 \%$ - 80\% dari tamu yang datang setiap harinya. Kerja sama yang dijalin hotel dengan OTA dalam menetapkan contract rate dan commission rate sebelum pandemic cukup memberikan tambahan occupancy rate bagi hotel. Hal ini memicu OTA untuk menerapkan pola tarik ulur dalam penetapan harga kamar dengan berbagai promonya. Dapat diartikan bahwa OTA ini menjadi nafas utama bisnis hotel Noormans selama pandemi di tahun 2020.

\section{Membuat Paket Program Hotel New Normal}

Dalam rangka peningkatan occupancy rate dan average room rate selama masa pandemi Covid-19, Hotel Noormans Semarang merencanakan dan melakukan adaptasi strategi yaitu:

a. Program staycation, yakni tamu diharapkan melakukan liburan yang dihabiskan di hotel dekat rumah dan melakukan aktivitas menyenangkan atau mengunjungi tempat-tempat wisata lokal sekitar hotel. Program ini kurang terukur dan hanya bisa memantau dari tipe tamu Walk in Guest yang proporsinya hanya 5\%-10\%.

b. Pay now stay later, program yang memungkinkan tamu bisa memesan kamar hotel dengan membayar selama pandemi dan bisa menginap di hotel pada waktu yang akan datang. Tidak ditemukan suatu keberhasilan dalam program ini.

c. Work from hotel dengan mengundang para tamu untuk bekerja dari hotel, untuk mengurangi kejenuhan dan stress selama bekerja dari rumah karena tidak 
diizinkan bekerja dari kantor tamu. Program ini hanya berjalan untuk acara fullboard dengan menerapkan social distancing.

d. Program Selabu (Selasa Rabu), yang menerapkan harga khusus bagi yang melakukan reservasi pada hari Selasa dan Rabu yang dikampanyekan melalui akun Instagram hotel. Setidaknya ada 2-4 reservasi kamar dari tamu personal dari setiap program ini.

e. Menggratiskan internet bagi pelajar. Ini sebagai program pengabdian dan bakti masyarakat yang diharapkan dapat menjadikan awareness kepada pelanggan atas kepedulian hotel ini.

Kenyataan yang terjadi di lapangan sungguh tidak mudah bagi Hotel Noormans Semarang dalam menjalankan berbagai strategi tersebut. Secara lengkap disajikan data occupancy rate sebagai berikut:

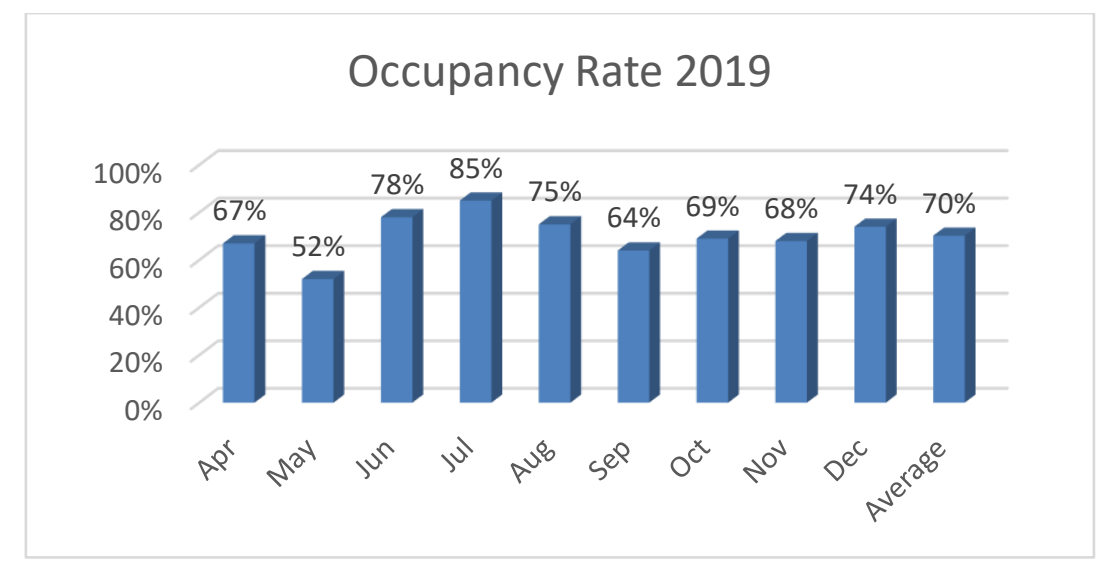

\section{Gambar 1. Occupancy rate tahun 2019 Hotel Noormans Semarang Sumber: Hotel Noormans, diolah.}

Pada tahun 2019 sebenarnya merupakan pencapaian occupancy rate tertinggi sejak Hotel Noormans Semarang berdiri tahun 2015. Pada periode April - Desember 2019, occupancy rate terendah pada angka 52\% dan tertinggi 85\% sehingga diperoleh rerata pada periode tersebut adalah $70 \%$. 
Izza Ulumuddin Ahmad Asshofi, Prima Setia Judha Pranata, Strategi Peningkatan Occupancy Rate dan Average Room Rate pada Masa Pandemi Covid-19 di Hotel Noormans Semarang

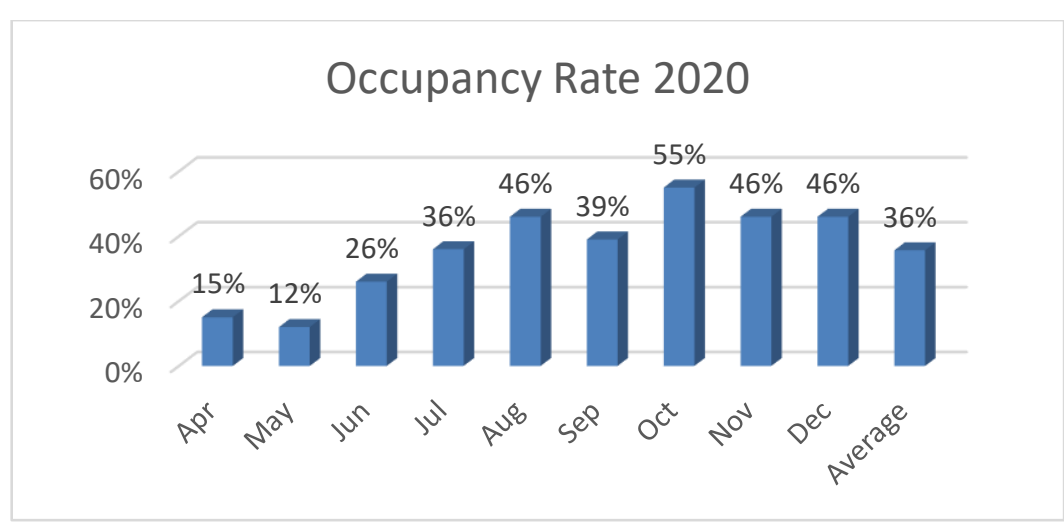

Gambar 2. Occupancy rate tahun 2020 Hotel Noormans Semarang [Sumber: Hotel Noormans, diolah]

Pada tahun 2020 ketika pandemi muncul, pada periode yang sama dari tahun sebelumnya, year to date April - Desember 2020, occupancy rate terendah pada angka $12 \%$ dan tertinggi 55\% sehingga diperoleh rerata pada periode tersebut adalah $36 \%$. Occupancy rate tertinggi pada tahun 2020 yaitu 55\% hanya unggul 3\% dibanding occupancy rate terendah tahun 2019 yakni 52\%. Sementara, rerata occupancy rate $70 \%$ tahun 2019 dibanding 36\% yang berarti mengalami penurunan rerata occupancy rate hampir setengah dari tahun sebelumnya sehingga strategi peningkatan occupancy rate belum berhasil menemui sasaran.

\section{Menurunkan Harga Kamar}

Berbagai strategi telah ditempuh untuk menaikkan occupancy rate. Namun, tidak menunjukkan hasil yang cukup positif. Di dalam situasi pandemi Covid-19 yang belum berakhir, terdapat berbagai macam kendala dalam strategi peningkatan occupancy rate dan average room rate sehingga kebijakan untuk menurunkan harga kamar tidak bisa dihindari untuk menarik tamu. Harga kamar dijual dengan harga minimal dengan mengambil profit seadanya agar tetap ada revenue bagi hotel.

Selain karena faktor pandemi, hal tersebut juga dipicu oleh kebijakan pemerintah yang sering berubah-ubah terkait PSBB dan PKM, pelarangan, pembatasan atau perizinan berkegiatan di hotel dengan jumlah tertentu, dan rencana vaksinasi yang belum ada kejelasan waktunya, seasonal marketing saat idul fitri yang 
pada saat itu larangan untuk keluar rumah sangat ketat. Hampir saja ada kesempatan untuk menaikkan occupancy rate dan average room rate saat libur natal dan tahun baru. Akan tetapi, secara mendadak muncul aturan baru tentang swab antigen yang hanya berlaku 3 hari sehingga banyak sekali reservasi yang dibatalkan.

Data penurunan rerata harga kamar disajikan dalam bentuk tabel berikut:

\section{Tabel 1. Average Room Rate Tahun 2019 dan 2020 dalam rupiah [Sumber: Hotel Noormans]}

$\begin{array}{lcc}\text { Bulan/Tahun } & \mathbf{2 0 1 9} & \mathbf{2 0 2 0} \\ \text { Apr } & 294,947 & 264,076 \\ \text { May } & 291,792 & 249,345 \\ \text { Jun } & 380,617 & 264,743 \\ \text { Jul } & 325,290 & 258,823 \\ \text { Aug } & 320,533 & 254,833 \\ \text { Sep } & 380,233 & 250,963 \\ \text { Oct } & 310,208 & 254,411 \\ \text { Nov } & 321,999 & 254,231 \\ \text { Dec } & 363,227 & 272,824 \\ \text { Average } & 332,094 & 258,250\end{array}$

Dari tabel tersebut nampak jelas bahwa average room rate mengalami penurunan dari tahun 2019 ke 2020 di semua bulan pada periode April - Desember. Pada 2019, rerata harga kamarnya mencapai Rp.332.094,00 dan tahun 2020 sebesar Rp.258.250,00 yang berarti selisihnya berjarak Rp.73.844,00. Suatu selisih penurunan average room rate yang cukup besar jika dikalikan dalam satu tahun.

Jika dilihat dari nominal, average room rate pada tahun 2019 hanya pada periode April dan Mei yang harganya di bawah Rp.300,000.00 dan selebihnya ada di atas harga Rp.300.000,00. Sementara pada tahun 2020, semua ARR di bawah harga Rp.300.000,00, bahkan rerata harga tertinggi hanya pada bulan Desember 2020 
Izza Ulumuddin Ahmad Asshofi, Prima Setia Judha Pranata, Strategi Peningkatan Occupancy Rate dan Average Room Rate pada Masa Pandemi Covid-19 di Hotel Noormans Semarang

sebesar Rp.272.824,00. Strategi yang mestinya diharapkan untuk dapat meningkatakan occupancy rate dan average room rate tetapi hasilnya adalah penurunan yang konstan.

Pada akhirnya, peningkatan occupancy rate dan average room rate di masa pandemi bukanlah sesuatu yang mudah dikerjakan dalam penjualan kamar hotel karena yang terjadi justru sebaliknya. Satu-satunya strategi yang ditempuh adalah dengan strategi bertahan, yaitu mempertahankan agar bisnis dan operasional tetap jalan (tidak ditutup) dengan fasilitas terbatas dan layanan yang tetap ramah sesuai dengan alokasi sumber daya yang ada di Hotel Noormans Semarang.

\section{SIMPULAN}

Strategi peningkatan occupancy rate dan average room rate di masa pandemi di hotel Noormans pada tahun 2020 tidak menunjukkan hasil yang positif. Akan tetapi, yang terjadi justru adalah sebaliknya, yaitu penurunan. Mengoptimalkan penjualan kamar melalui online travel agent (OTA) dan menerapkan strategi bertahan menjadi strategi andalan untuk mempertahankan bisnis dan operasionalnya agar tidak ditutup meskipun dengan occupancy rate dan average room rate yang mengalami penurunan.

\section{REFERENSI}

Abdullah, Abdul Aziz and Hamdan, Mohd Hairil. (2012). "Internal Success Factor of Hotel Occupancy Rate", International Journal of Business and Social Science, Vol. 3 No. 22.

Basuki, Sulistyo. (2010). Metode Penelitian. Jakarta: Wedatama Widya Sastra.

Christanto, F. (2014). Analisis Penjualan Melalui Media Online Di Pt Wahana Travel Indonesia. Jurnal Program Manajemen Bisnis Universitas Petra.

Data Covid 19 di Indoneisa (www.covid19.go.id, diakses tanggal 16 April 2020).

Data Covid-19 di dunia (www.ourworldindata.org/coronavirus, diakses tanggal 16 April 2020).

David, Fred R.. (2011). Manajemen Strategis Konsep: Edisi 12. Jakarta: Salemba Empat.

Freddy Rangkuti. (2015). Analisis SWOT. Jakarta : Gramedia.

Global Forecast and Profiles of Market Segments (English version). (2020). https://www.e-unwto.org/doi/pdf/10.18111/9789284404667 Tourism 2020 Vision Vol. 7. 
Impact assessment of the Covid-19 outbreak on international tourism. (2020). https://www.unwto.org/impact-assessment-of-the-covid-19-outbreak-oninternational-tourism

PHRI. (2020). Laporan Perkembangan Hotel dan Restoran.

PHRI. (2020). Laporan Hotel yang Ditutup.

PP No. 21 tahun 2020 tentang Pembatasan Sosial Berskala Besar (PSBB) dalam rangka Percepatan Penanganan Corona Virus Disease (COVID-19).

Prediksi Pariwisata Ramai

https://www.tagar.id/imbas-wfh-wishnutama-prediksi-pariwisata-ramai-2021diakses tanggal 16 April 2020).

Sugiarto, Endar. (2004). Front Office Hotel Administration. Jakarta: Gramedia Sugiyono. (2018). Metode Penelitian Pendidikan. Bandung: Alfabeta.

The Impact of Coronavirus on the Global Economy. (2020). Passport. Euromonitor International.

Umar, Husein. (2010). Desain Penelitian Manajemen Strategik. Jakarta: Rajawali Pers.

UU No 6 tahun 2018 tentang Kekarantinaan Kesehatan.

Viglia, G., Minazzi, R. and Buhalis, D.. (2016), "The influence of e-word of mouth on hotel occupancy rate", International Journal of Contemporary Hospitality Management, Vol. 28 No. 9, pp. 2035-2051. https://doi.org/10.1108/IJCHM$\underline{05-2015-0238}$ 